\title{
Pemahaman Konsep Siswa Pada Materi Bangun Datar Terhadap Hasil Belajar Dimensi Tiga
}

\author{
Malik Ibrahim \\ Sistem Informasi, Universitas Nahdlatul Ulama NTB, malikedu.org@gmail.com
}

\begin{tabular}{l} 
INFO ARTIKEL \\
\hline Riwayat Artikel: \\
Diterima: 08-07-2018 \\
Disetujui: 20-10-2018 \\
\end{tabular}

\section{Kata Kunci:}

Pemahaman Konsep,

Hasil Belajar,

Bangun Datar,

Dimensi Tiga

\begin{abstract}
ABSTRAK
Abstrak: Penelitian ini bertujuan untuk mengetahui seberapa besar pengaruh pemahaman konsep siswa pada materi bangun datar terhadap hasil belajar dimensi tiga kelas X MA. Hidayatul Muhsinin Labulia. Penelitian ini menggunakan pendekatan kuantitatif jenis EX Post Facto desain hubungan kausalitas yaitu hubungan yang bersifat sebab akibat. Penelitian ini menggunakan penelitian populasi yang jumlah keseluruhannya adalah 109 siswa terdiri dari kelas XA, XB dan XC. Hasil penelitian menunjukkan pengaruh pemahaman konsep bangun datar cukup berpengaruh positif terhadap hasil belajar dimensi tiga. Hal ini terlihat pada hasil penelitian dengan melakukan pemberian tes kepada 109 siswa. Hubungan antara pemahaman konsep bangun datar dan hasil belajar dimensi tiga sebesar 0,668 atau 66,8\%, ini berarti korelasi antara pemahaman konsep bangun datar dan hasil belajar dimensi tiga adalah cukup, sesuai dengan kriteria yang telah ada. Adapun pengaruh antara pemahaman konsep bangun datar dan hasil belajar dimensi tiga sebesar 0,447 atau 44,7\%. Sedangkan persamaan regresi antara pemahaman konsep bangun datar dan hasil belajar dimensi tiga adalah $\mathrm{Y}=8,831+0,934 \mathrm{X}$, ini menjelasakan bahwa keterkaitan antara pemahaman konsep bangun datar dengan hasil belajar dimensi tiga bersifat searah (positif) atau dengan kata lain bahwa, jika tingkat pemahman konsep bangun datar tinggi maka akan mengakibatkan hasil belajar dimensi tiga tinggi pula, dan demikian pula sebaliknya. Berdasarkan penjelasan tersebut dapat disimpulkan bahwa terdapat pengaruh positif pemahaman konsep bangun datar terhadap hasil belajar dimensi tiga.
\end{abstract}

\begin{abstract}
This research aims to find out how much impact the students' conceptual understanding of the material is flat on the learning outcomes of the three dimensions of class X MA. Hidayatul Muhsinin Labulia. This study uses a quantitative approach to the type of Ex Post Facto design causality relationship that is causal relationships. This study uses a population research whose total number is 109 students consisting of classes $X A, X B$ and $X C$. The results of the study showed that the impact of understanding the flat wake concept was quite a positive effect on the learning outcomes of three dimensions. This can be seen in the results of the study by giving tests to 109 students. The relationship between understanding the concept of flat wake and three dimensional learning outcomes is 0.668 or $66.8 \%$, this means that the correlation between understanding the concept of flat wake and three dimensional learning outcomes is sufficient, according to existing criteria. The influence between the understanding of the concept of flat wake and the third dimension of learning outcomes is 0.447 or $44.7 \%$. While the regression equation between understanding the concept of flat wake and three dimensional learning outcomes is $Y=8.831+0.934 X$, this explains that the relationship between understanding the concept of flat wake with learning outcomes of three dimensions is unidirectional (positive) or in other words that, if the level of understanding concept wake up high then it will result in high three dimensional learning outcomes too, and vice versa. Based on these explanations, it can be concluded that there is a positive influence on understanding the concept of flat building on the results of three dimensional learning.
\end{abstract}




\section{A. LATAR BELAKANG}

Matematika merupakan salah satu bidang studi yang menduduki peranan penting dalam pendidikan dan kehidupan masyarakat. Hal ini dapat dilihat dari jam pelajaran matematika lebih banyak bila dibanding dengan pelajaran yang lain. Maka dari itu setiap siswa perlu memiliki penguasaan matematika pada tingkat tertentu. Namun banyak siswa yang masih mengalami kesulitan dalam belajar matematika, kesulitan belajar ini merupakan suatu kondisi dimana siswa mengalami hambatan dalam belajar. Adapun hambatan belajar tersebut dikemukakan oleh Lerner dalam Mulyono yaitu (1) adanya gangguan dalam hubungan keruangan, (2) abnormalitas persepsi visual, (3) asosiasi visualmotor, (4) perseverasi, (5) kesulitan mengenal dan memahami symbol, (6) gangguan penghayatan tubuh, (7) kesulitan dalam bahasa dan membaca, dan (8) Performance IQ jauh lebih rendah daripada sekor Verbal IQ. Sehingga dapat mempengaruhi prestasi belajar siswa.

Namun pada dasarnya belajar matematika merupakan belajar konsep, sedangkan konsepkonsep dasar matematika merupakan kesatuan yang bulat dan utuh. Untuk itu dalam proses belajar mengajar yang terpenting adalah bagaimana guru dapat mengajarkan konsep itu, dan siswa dapat memahaminya. Karena banyak unsur yang secara bersama-sama dapat mempengaruhi keberhasilan pembelajaran matematika. Diantara unsur-unsur yang mempengaruhi antara lain: siswa/mahasiswa, pendidik/guru/dosen, metode pembelajaran, lingkungan. Namun faktor yang paling dominan adalah terletak pada tingkat penguasaan konsep.

Konsep menunjuk pada pemahaman dasar. Siswa mengembangkan suatu konsep ketika mereka mampu mengklasifikasikan atau mengelompokkan benda-benda atau ketika mereka dapat mengasosiasikan suatu nama dengan kelompok benda tertentu. Walaupun pengajaran matematika dilakukan dengan memperhatikan urutan konsep dan dimulai dari hal yang sederhana, tetapi sampai saat ini matematika masih dianggap sebagai pelajaran yang sulit dan perolehan nilai terendah. Akibatnya banyak siswa yang bersikap acuh dalam proses belajar mengajar matematika yang berdampak pada hasil belajar mereka.

Hasil observasi peneliti menunjukkan bahwa masalah yang dialami oleh siswa-siswi MA Hidayatul Muhsinin dalam belajar adalah kesulitan dalam menyelesaikan persoalan dimensi tiga yang berkaitan dengan bangun datar seperti halnya dalam menentukan jarak antara bidang dengan bidang dan semacamnya. Selain itu, hasil belajar siswa yang masih di bawah rata-rata yaitu 37,89 merupakan salah satu indikasi bahwa adanya kesenjangan yang dialami siswa dalam memahami konsep dasar materi dimensi tiga yang ada keterkaitannya dengan bangun datar. Adapun standar ketuntasan belajar yang dijadikan acuan oleh madrasah MA Hidayatul Muhsinin yaitu nilai minimal 75.

Hasil wawancara peneliti juga dengan guru mata pelajaran matematika MA Hidayatul Muhsinin bahwa siswa-siswi masih kesulitan dalam mempelajari materi dimensi tiga khususnya yang ada unsur keterkaitannya dengan bangun datar, meskipun segala upaya telah dilakukan untuk mengatasi masalah tersebut. Salah satunya adalah dengan menggunakan metode pembelajaran kooperatif yaitu metode jigsaw dan CTL. Berdasarkan beberapa uraian di atas, maka peneliti ingin melakukan sebuah penelitian menggunakan pendekatan kuantitatif dengan judul "Pemahaman Konsep Siswa pada Materi Bangun Datar Terhadap Hasil Belajar Dimensi Tiga Kelas X MA Hidayatul Muhsinin Labulia".

\section{B. METODE PENELITIAN \\ 1. Pendekatan Penelitian}

Dalam penelitian ini peneliti menggunakan pendekatan kuantitatif dengan jenis penelitian ex post facto desain hubungan kausalitas yaitu hubungan yang bersifat sebab akibat, hal ini disebabkan karena penelitian yang dilakukan setelah suatu peristiwa itu terjadi. Jenis penelitian ex post facto sering disebut dengan after the fact artinya penelitian yang dilakukan setelah suatu kejadian itu terjadi. Kerlinger memberikan batasan penelitian ex post facto dengan cukup ringkas yaitu "Penyelidikan empiris yang sistematis di mana ilmuan tidak mengendalikan variabel bebas secara langsung karena perwujudan variabel tersebut telah terjadi, atau karena variabel tersebut pada dasarnya memang tidak dapat dimanipulasi.

\section{Instrumen dan Kehadiran Peneliti}

Instrument penelitian adalah suatu alat yang digunakan untuk mengukur fenomena alam maupun sosial yang diamati. Dalam penelitian ini peneliti menggunakan instrument tes. Instrumen Tes adalah serentetan pertanyaan atau latihan serta alat lain yang digunakan untuk mengukur keterampilan, pengetahuan intelegensi, kemampuan atau bakat yang dimiliki oleh individu atau kelompok. Dalam penelitian ini, peneliti menggunakan tes bangun datar dan tes dimensi tiga yang dapat mengukur pengaruh kedua materi tersebut.

a. Tes Bangun Datar

Adapun kisi-kisi instrumen penelitian yang peneliti gunakan sebagai berikut.

TABEL 1

KISI-KISI INSTRUMEN PENELITIAN

\begin{tabular}{|c|c|c|c|}
\hline Variabel & Indikator & Ket & No. Item \\
\hline \multirow{3}{*}{$\begin{array}{l}\text { Bangun } \\
\text { Datar } \\
\text { (Segitiga, } \\
\text { Segiempat } \\
\text { ), }\end{array}$} & $\begin{array}{l}\text { Menentukan salah satu } \\
\text { besar sudut pada segitiga }\end{array}$ & $\mathrm{C} 2$ & 1 \\
\hline & $\begin{array}{l}\text { Menentukan panjang } \\
\text { unsur-unsur segitiga }\end{array}$ & $\mathrm{C} 2$ & 2 \\
\hline & Menentukan panjang & $\mathrm{C} 2$ & 3 \\
\hline
\end{tabular}




\begin{tabular}{llll}
\hline $\begin{array}{l}\text { lingkaran, } \\
\text { poligon. }\end{array}$ & $\begin{array}{l}\text { unsur-unsur segiempat } \\
\text { Menghitung keliling dan }\end{array}$ & C3 & 4 \\
\hline & $\begin{array}{l}\text { luas segitiga } \\
\begin{array}{l}\text { Menghitung keliling dan } \\
\text { luas segiempat }\end{array}\end{array}$ & C3 & 5 \\
\hline $\begin{array}{l}\text { Menghitung keliling dan } \\
\text { luas lingkaran }\end{array}$ & C3 & 6 \\
\hline $\begin{array}{l}\text { Menghitung luas } \\
\text { lingkaran jika di dalam } \\
\text { lingkaran C4 } \\
\text { daerah yang diarsir }\end{array}$ & 7,8 \\
& $\begin{array}{l}\text { Menghitung luas dari } \\
\text { gabungan } \\
\text { bangun datar beberapa }\end{array}$ & C6 & 9,10 \\
\hline
\end{tabular}

b. Tes Dimensi Tiga

Adapun kisi-kisi instrumen penelitian yang peneliti gunakan sebagai berikut.

TABEL 2

KISI-KISI INSTRUMEN PENELITIAN

\begin{tabular}{|c|c|c|c|}
\hline Variabel & Indikator & Ket & No. Item \\
\hline \multirow{8}{*}{$\begin{array}{l}\text { Dimensi } \\
\text { Tiga } \\
\text { (Limas, } \\
\text { Kerucut, } \\
\text { dan Bola) }\end{array}$} & $\begin{array}{l}\text { Menentukan jarak antara } \\
\text { titik dengan bidang pada } \\
\text { bangun ruang }\end{array}$ & $\mathrm{C} 2$ & 1 \\
\hline & $\begin{array}{l}\text { Menentukan jarak antara } \\
\text { titik dengan garis pada } \\
\text { bangun ruang }\end{array}$ & $\mathrm{C} 2$ & 2,3 \\
\hline & $\begin{array}{l}\text { Menghitung besar sudut } \\
\text { antara garis dan bidang } \\
\text { pada bangun ruang }\end{array}$ & C3 & 4 \\
\hline & $\begin{array}{l}\text { Menghitung luas } \\
\text { permukaan, selimut dan } \\
\text { volume kerucut }\end{array}$ & C3 & 5 \\
\hline & $\begin{array}{l}\text { Menghitung luas } \\
\text { permukaan dan volume } \\
\text { bola }\end{array}$ & C3 & 6 \\
\hline & 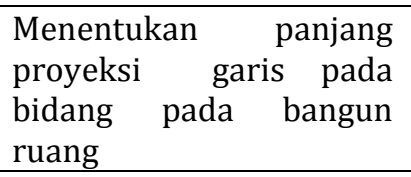 & C3 & 7,8 \\
\hline & $\begin{array}{l}\text { Menentukan besar sudut } \\
\text { antara bidang } \\
\text { bidang pada bangan } \\
\text { ruang }\end{array}$ & C6 & 9 \\
\hline & $\begin{array}{l}\text { Menentukan jarak antara } \\
\text { bidang dengan bidang } \\
\text { pada bangun ruang }\end{array}$ & $\mathrm{C} 4$ & 10 \\
\hline
\end{tabular}

\section{Objek Penelitian}

Objek penelitian ini adalah seluruh siswa-siswi kelas X MA Hidayatul Muhsinin yang terdiri dari 35 orang kelas XA, 35 orang kelas XB, 39 orang kelas XC.

\section{Teknik Pengumpulan Data}

Teknik pengumpulan data merupakan langkah yang paling strategis dalam penelitian, karena tujuan utama dari penelitian adalah mendapatkan data. Dalam melakukan penelitian metode pengumpulan data sangat diperlukan guna memperoleh data yang diperlukan atau dibutuhkan.
Pertama, metode tes yakni suatu cara atau teknik untuk mengukur kemampuan dasar intelegensi (IQ) siswa. Metode ini digunakan untuk mendapatkan data hasil belajar siswa. Penelitian ini menggunakan penelitian empiris, maka semua siswa yang menjadi populasi penelitian ini akan diberikan tes. Tes pertama materi bangun datar dan tes yang kedua adalah materi dimensi tiga. Kedua, dokumentasi atau mencari data mengenai hal-hal atau variabel yang berupa catatan, buku, surat kabar, tempat, agen, lager dan sebagainya.

\section{Teknik Analisa Data}

Data yang diperoleh peneliti tidak cukup untuk menyimpulkan hasil penelitian, akan tetapi data tersebut perlu untuk dianalisis. Hipotesis yang telah dirumuskan akan diuji dengan Statistik Parametris. Oleh karena itu, dalam menentukan keberhasilan suatu penelitian, hal yang mutlak dilakukan adalah analisis data. Oleh sebab itu, dalam penelitian ini peneliti menggunakan teknik analisis data yang disesuaikan dengan rumusan masalah yang diajukan.

a. Uji normalitas yang menjadi uji prasyarat pada penelitian ini adalah chi kuadrat $\left(X^{2}\right)$. Adapun rumus yang digunakan sebagai berikut:

$X^{2}=\sum \frac{(o i-E i)^{2}}{E i}$

Uji normalitas memiliki kriteria yaitu $\mathrm{X}^{2}$ hitung $<\mathrm{X}^{2}$ tabel maka data tersebut berdistribusi normal pada derajat kebebasan $(\mathrm{dk})=\mathrm{n}-1$ dengan $\alpha=5 \%=0,05$.

b. Regresi sederhana yang didasarkan pada hubungan fungsional ataupun kausal satu variabel independen dengan satu variabel dependen. Dalam penelitian ini peneliti menggunakan analisa regresi linear sederhana dengan persamaan umumnya adalah:

$Y=a+b X$

c. Teknik korelasi product moment merupakan salah satu teknik untuk mencari tingkat keeratan hubungan antara dua variabel dengan cara mengalikan momen-momen (hal-hal penting) kedua variabel tersebut. Penelitian ini menggunakan korelasi product moment sebagai teknik analisa data yang bertujuan untuk mengetahui keterkaitan antara materi bangun datar dengan hasil belajar dimensi tiga.

Secara umum, rumusnya dapat dituliskan sebagai berikut :

$$
r_{x y}=\frac{n \sum X Y-\left(\sum X\right)\left(\sum Y\right)}{\sqrt{\left(n \sum X^{2}-\left(\sum X\right)^{2}\right)\left(n \sum Y^{2}-\left(\sum Y\right)^{2}\right)}}
$$




\section{HASIL DAN PEMBAHASAN}

\section{Analisis Data}

Analisis data dilakukan untuk mengolah data hasil penelitian. Adapun analisis yang digunakan peneliti yaitu analisis regresi linear sederhana dan koefesien korelasi.

\section{a. Analisis Regresi Linear Sederhana}

Berdasarkan hasil analisis regresi linear sederhana menggunakan program SPSS 17.0 dapat dilihat pada tabel coefficients untuk harga a yaitu 8,831 dan harga b yaitu 0,934.

\begin{tabular}{|ll|r|r|}
\hline \multicolumn{1}{|c}{ Correlations } \\
\hline Pearson Correlation & DimensiTigaY & BangunDatarX \\
& DimensiTigaY & 1.000 & .668 \\
& BangunDatarX & .668 & 1.000 \\
\hline Sig. (1-tailed) & DimensiTigaY & & .000 \\
& BangunDatarX & .000 & 109 \\
\hline N & DimensiTigaY & 109 & 109 \\
\hline
\end{tabular}

Gambar 1. Output analisis koefesien korelasi (r)

Hasil analisis untuk mengetahui koefisien korelasi berdasarkan tabel Correlations menginformasikan besar hubungan (korelasi) antara variabel dependen (hasil belajar dimensi tiga) dan variabel independen (pemahaman konsep bangun datar). Tabel tersebut menunjukkan bahwa pemahaman konsep bangun datar berpangaruh sebesar 0,668 atau $66,8 \%$ terhadap hasil belajar dimensi tiga. Korelasi berada pada kategori cukup tinggi.

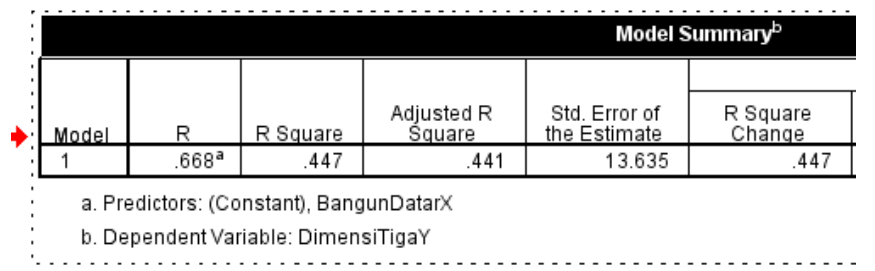

Gambar 2. Output analisis koefesien determinasi $\left(\mathrm{r}^{2}\right)$

Tabel Model Summaryb menginformasikan besarnya koefisien korelasi ( $\mathrm{r}$ ) dan koefisien determinasi $\left(\mathrm{r}^{2}\right)$. Koefisein determinasi adalah proporsi variansi total variabel dependen dapat dijelaskan oleh variabel independen melalui hubungan linear tersebut. Dalam hal ini, proporsi hasil belajar dimensi tiga dapat dijelaskan oleh pemahaman bangun datar sebesar 0,447 atau 44,7 \%.

\section{b. Menguji Linearitas}

\begin{tabular}{|ll|r|r|r|l|r|}
\hline Model & & Sum of Squares & \multicolumn{1}{|c|}{ Df } & Mean Square & F & \multicolumn{1}{c|}{ Sig. } \\
\hline 1 & Regression & 16051.056 & 1 & 16051.056 & 86.331 & $.000^{3}$ \\
& Residual & 19893.898 & 107 & 185.924 & & \\
Total & 35944.954 & 108 & & & \\
\hline
\end{tabular}

a. Predictors: (Constant), BangunDatarX

b. Dependent Variable: DimensiTigaY

Gambar 3. Output analisis linieritas
Pada pengujian linearitas ini dapat diketahui dari tabel output analisis SPSS tabel anovab seperti tabel diatas. Nilai yang digunakan untuk mengetahui linearitas regresi adalah jika Fhitung > Ftabel dan nilai Sig. $<\alpha$ maka model liniear antara pemahaman konsep bangun datar dengan hasil belajar dimensi tiga signifikan, dan tidak signifikan jika sebaliknya.

Fhitung $=86,331$ dan $\alpha=0,05=5 \%$ sedangkan Ftabel $=(2 ; 107 ; 0,05)=1,98$. Karena Fhitung $>$ FTabel, maka model linear antara variabel pemahaman konsep bangun datar dengan hasil belajar dimensi tiga signifikan. Selain itu, dapat juga dilihat dari perbandingan nilai Sig. dan $\alpha$. Karena Sig. $(0,000)<\alpha(0,05)$, maka model linear antara variabel pemahaman konsep bangun datar dengan hasil belajar dimensi tiga signifikan.

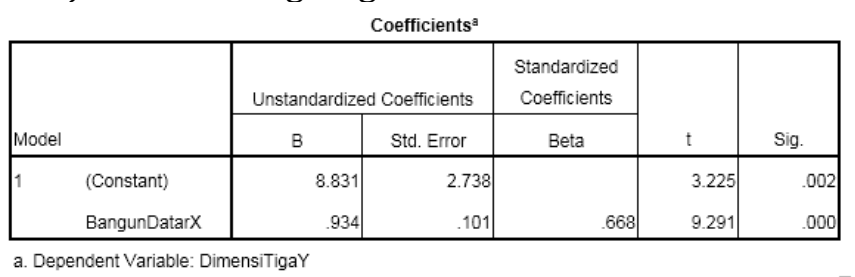

Gambar 4. Output analisis persamaan regresi linier sederhana

Hasil analisis SPSS 17.0 untuk mengetahui nilai a dan b yang diperoleh dapat diketahui dari kolom Coefficientsa. Berdasarkan hasil analisis tersebut diperoleh nilai $\mathrm{a}=8,831$ (kolom Unstandardized Coefficients B baris Constant) dan $\mathrm{b}=0,934$ (kolom Unstandardized Coefficients B Bangun Datar X) sehingga persamaan regresi yang terbentuk adalah :

$\mathrm{Y}=8,831+0,934 \mathrm{X}$

Nilai koefisien a sebesar 8,831 menunjukkan Y (hasil belajar dimensi tiga) ketika $X$ (pemahaman konsep bangun datar) $=0$. Nilai koefisien $b$ sebesar 0,934 yang bernilai positif menunujukkan arah peningkatan atau penurunan variabel dependen yang didasarkan pada perubahan variabel independen. Persamaan regresi yang telah ditemukan dapat digunakan untuk melakukan prediksi (ramalan) bagaimana individu dalam variabel dependen akan terjadi bila individu dalam variabel independen ditetapkan. Artinya jika tingkat pemahaman konsep bangun datar tinggi maka hasil belajar dimensi tiga tinggi, begitu pula sebaliknya.

\section{c. Signifikan Koefesien Regresi}

Pada table Coefficientsa diatas, digunakan juga untuk mengetahui tentang signifikansi koefisien regresi yang dimiliki. Hal ini diketahui dengan melihat nilai thitung dengan membandingkannya pada ttabel dan nilai Sig. dengan membandingkannya pada nilai $\alpha$. Untuk mengetahui koefisien regresi signifikan atau tidak, maka diperlukan hipotesis sebagai berikut:

$\mathrm{H}_{0}=$ keofisien tidak signifikan

$\mathrm{H}_{1}=$ keofisien signifikan 
Untuk koefisien $\mathrm{a}=8,831, \mathrm{t}_{\text {hitung }}=3,225, \mathrm{t}_{\text {tabel }}=1,98$. untuk $\mathrm{dk}=107$ dan $\alpha=0,05$. Karena $t_{\text {hitung }}>t_{\text {tabel }}$ maka $\mathrm{H}_{0}$ ditolak. Hal ini berarti bahwa koefisien a signifikan. Hal ini dapat juga dilihat dari nilai Sig. nilai Sig. $(0,002)<\alpha(0,05)$ sehingga $H_{0}$ ditolak. Untuk koefisien $b=0,934$. $t_{\text {hitung }}=9,291 ; t_{\text {tabel }}=1,98$. untuk $\mathrm{dk}=107$ dan $\alpha=0,05$. Karena $t_{\text {hitung }}>t_{\text {tabel }}$ maka $\mathrm{H}_{0}$ ditolak. Hal ini berarti bahwa koefisien b signifikan. Hal ini dapat juga dilihat dari nilai Sig. nilai Sig. $(0,000)<\alpha(0,05)$ sehingga $\mathrm{H}_{0}$ ditolak.

\section{Hasil Analisis}

Dari hasil analisis menunjukkan bahwa nilai thitung $=9,291$ setelah dicocokkan dengan ttabel pada taraf signifikansi $5 \%$ dan derajat bebas penyebut $\mathrm{db}=\mathrm{N}-2$ dan derajat bebas pembilang $=1$, diperoleh $t_{\text {tabel }}=$ 1,98. Artinya $t_{\text {hitung }}>t_{\text {tabel. }}$. Hal ini berarti $t_{\text {hitung yang }}$ diperoleh adalah signifikan, ini menunjukkan bahwa persamaan regresi yang diperoleh adalah $\mathrm{Y}=8,831+$ $0,934 \mathrm{X}$ bisa digunakan untuk menganalisis hubungan antara X dan Y.

\section{Contoh 1:}

Misalkan untuk ramalan nilai maksimal $\mathrm{X}=50$

$$
\begin{aligned}
\mathrm{Y} & =8,831+0,934 \mathrm{X} \\
& =8,831+0,934(50) \\
& =8,831+46,7 \\
& =55,531
\end{aligned}
$$

Berdasarkan ramalan diatas, jika siswa yang mempunyai pemahaman konsep bangun datar (X) mendapat nilai 50 diharapkan/diperkirakan siswa akan memperoleh hasil dimensi tiga (Y) adalah sebesar 55,531. Dengan demikian, ini berarti bahwa persamaan regresi ini dapat digunakan untuk

\begin{tabular}{|c|c|c|c|c|}
\hline \multirow[t]{2}{*}{ 国 } & \multicolumn{4}{|c|}{$\begin{array}{l}\text { Wilcoxon Signed Ranks Test } \\
\text { Ranks }\end{array}$} \\
\hline & & $\mathrm{N}$ & Mean Rank & Sum of Ranks \\
\hline \multirow[t]{4}{*}{$y-x$} & Negative Ranks & $21^{13}$ & 46.00 & 966.00 \\
\hline & Positive Ranks & $71^{\circ}$ & 46.65 & 3312.00 \\
\hline & Ties & $17^{\circ}$ & & \\
\hline & Total & 109 & & \\
\hline \multicolumn{5}{|c|}{ a. $Y<X$} \\
\hline \multicolumn{5}{|c|}{ b. $Y>X$} \\
\hline \multicolumn{5}{|c|}{ c. $Y=X$} \\
\hline
\end{tabular}
menentukan antara pemahaman konsep bangun datar dengan hasil belajar dimensi tiga.

\section{Pengujian Hipotesis}

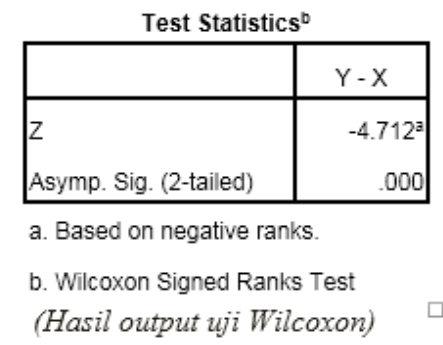

Gambar 5. Output pengujian hipotesis dengan uji Wilcoxon
Berdasarkan output di atas dapat diketahui bahwa untuk output Rank menjelaskan tentang jumlah data, rata-rata peringkat, dan jumlah peringkat. Sedangkan untuk output Test Statistic menjelaskan tentang uji statistik berupa nilai $\mathrm{Z}$ dan signifikansi. Untuk kriteria pengujian uji Wilcoxon, Ho diterima jika siginifikansi > 0,05, dan Ho ditolak jika signifikansi < 0,05 atau berdasarkan nilai dari $Z_{\text {hitung }}$ dan $Z_{\text {tabel, }}$, Ho diterima jika $Z_{\text {hitung }}<Z_{\text {tabel }}$ begitu juga sebaliknya.

Berdasarkan penjelasan di atas dapat diketahui untuk nilai signifikansi yaitu 0,000 dan nilai $Z=-$ 4,712 atau dimutlakkan menjadi $Z=4,712$. Karena nilai signifikansi 0,000 kurang dari 0,05 maka Ho ditolak. Selain itu berdasarkan nilai $Z_{\mathrm{hitung}}=4,712$ dan $\mathrm{Z}_{\text {tabel }}=1,64$ pada taraf signifikan 0,05 , ini menunjukkan bahwa $Z_{\text {hitung }}>Z_{\text {tabel. }}$. Dengan ditolaknya hipotesis nol (Ho), maka peneliti menerima hipotesis alternatif ( $\mathrm{Ha}$ ) yang berbunyi "Terdapat Pengaruh Positif Pemahaman Konsep Bangun Datar Terhadap Hasil Belajar Dimensi Tiga".

\section{Pembahasan}

Berdasarkan hasil analisis diatas terlihat bahwa pemahaman konsep bangun datar (X) terhadap hasil belajar dimensi tiga $(\mathrm{Y})$ memiliki hubungan positif. Hal ini dapat dilihat dari persamaan regresi linier sederhana yaitu $Y=8,831+0,934 X$, persamaan regresi linier sederhana tidak perlu untuk diuji kelinierannya karena persamaan tersebut sudah linier hal ini dapat dilihat dari persamaan yang berpangkat satu. Sedangkan untuk uji keberartian regresi $Y$ atas $X$ diperoleh $t_{\text {hitung }}=9,291$ dengan $\mathrm{dk}$ pembilang $=1$ dan dk penyebut $=\mathrm{N}-2$ dengan taraf nyata $0,05(5 \%)$ yaitu $t_{\text {tabel }}=1,98$ (lampiran 10) jadi $t_{\text {hitung }}>t_{\text {tabel }}$, sehingga persamaan regresi ini berarti dan dapat digunakan untuk membuat kesimpulan mengenai hubungan dan pertautan antara $Y$ atas $X$.

Dari hasil analisis regresi linier sederhana menggunakan SPSS. 17.0 diperoleh antara variabel X dengan variabel Y yang ditunjukkan oleh $r^{2}$ diperoleh sebesar 0,447 merupakan koefesien korelasi antara variabel X dengan variabel $Y$. hal ini berarti bahwa semakin besar nilai $r$ maka semakin besar pula nilai dengan variabel X nilai dari variabel Y. Dari pengujian hipotesis dapat dilihat bahwa nilai $Z_{\text {hitung }}>Z_{\text {tabel }}$ maka, Ha diterima dan Ho ditolak. Jadi terdapat hubungan positif dan signifikan antara variabel $\mathrm{X}$ dengan variabel $Y$ sebesar 0,447 atau dengan kata lain variabel $\mathrm{X}$ berpengaruh terhadap variabel $\mathrm{Y}$ sebesar $44,7 \%$, sedangkan 55,3\% variabel $Y$ dipengaruhi oleh faktor lain, dan $r^{2}$ merupakan koefesien determinasi yang besarnya adalah kuadrat dari koefesien korelasi, koefesien ini disebut koefesien penentu, karena varian yang terjadi pada variabel dependen dapat dijelaskan melalui varian yang ada pada variabel independen. Hal ini berarti pula bahwa pemahaman konsep bangun datar merupakan materi dasar yang harus dipelajari untuk mempelajari 
dimensi tiga. Hal ini senada dengan apa yang dijelaskan oleh karso bahwa "suatu ilmu dalam matematika harus memiliki prasyarat pemula untuk dapat mempelajari ilmu berikutnya". Hal ini menunjukkan kepada kita bahwa untuk dapat menyelesaikan dimensi tiga dengan baik maka kita harus menguasai terlebih dahulu pemahaman tentang bangun datar.

\section{SIMPULAN DAN SARAN}

Berdasarkan penelitian yang telah dilakukan maka peneliti dapat menyimpulkan beberapa hal sebagai berikut:

1. Pemahaman konsep bangun datar memiliki pengaruh positif terhadap hasil belajar dimensi tiga.

2. Untuk dapat menyelesaikan soal dimensi tiga dengan baik, maka harus menguasai konsep bangun datar.

3. Bagi pendidik, hendaknya mengutamakan pengajaran yang berorientasi pada pemahaman konsep.

4. Bagi siswa, hendaknya memanfaatkan buku penunjang sebagai acuan untuk menambah pengetahuan mengenai pemahaman konsep bangun datar khususnya yang dapat memberikan konstribusi pada materi dimensi tiga dengan cara banyak latihan mengerjakan soal-soal yang dapat menumbuh kembangkan pemahaman konsep bangun datar.

\section{REFERENSI}

[1] Abdurrahman, Mulyono. (2003). Pendidikan Bagi Anak Berkesulitan Belajar. Jakarta: Rineka Cipta

[2] Irzani, dkk. (2010). Matematika 1 Untuk Calon Guru $S D / M I$. Yogyakarta: Kurnia Salam Semesta.

[3] Suprijono, Agus. (2010). Cooperative Learning Teori dan Aplikasi PAIKEM. Yogyakarta: Pustaka Pelajar

[4] Slameto. (2010). Belajar dan Faktor-faktor yang Mempengaruhi. Jakarta: Rineka Cipta

[5] Suharsimi. (2010). Prosedur Penelitian Suatu Pendekatan Praktik. Jakarta: Rineka Cipta.

[6] Iskandar. (2009). Metodologi Penelitian Pendidikan dan Sosial (Kuantitatif \& Kualitatif). Jakarta: GP Press.

[7] Priyatno, Duwi. (2011). Buku Saku Analisis Statistik Data SPSS. Yogyakarta: MediaKom

[8] Nila Kusumawati. (2008). Pemahaman Konsep Matematik dalam Pembelajaran Matematika. Semnas Matematika dan Pendidikan Matematika 2008, 229235.

[9] Hadiyanti. (2012). Keefektifan Pembelajaran Kooperatif Numbered Head Together Terhadap Kemampuan Pemahaman Konsep. Unnes Journal of Mathematics Education, 1 (1). 